\title{
Trade liberalization and the balance of payments constraint with intermediate imports: the case of Mexico revisited
}

\author{
Robert A. Blecker ${ }^{\mathrm{a}}$, Carlos A. Ibarra
}

December 2012

\begin{abstract}
Previous studies have found that a tightening of the balance of payments (BP) constraint can explain the slowdown in Mexico's growth after its trade liberalization in the late 1980s. This paper develops a disaggregated model of the BP constraint with two types of exports (manufactured and primary commodities) and two types of imports (intermediate and final goods). Econometric estimates (including tests for structural breaks) show that the BPequilibrium growth rate did not fall, but instead rose in the post-liberalization period, so this model cannot account for the country's growth slowdown. Instead, the analysis points to the need to consider the real exchange rate as well as internal obstacles and policies.
\end{abstract}

Keywords: Mexican economy; balance-of-payments constraint; trade liberalization; intermediate imports

JEL classifications: F43, F14, E12, O24

${ }^{a}$ Department of Economics, American University, 4400 Massachusetts Ave., N.W., Washington, DC 20016, USA, blecker@american.edu. [Corresponding author: Tel. +1-202-885-3767;

Fax +1-202-885-3790]

${ }^{\mathrm{b}}$ Departamento de Economía, Universidad de las Américas Puebla, Sta. Catarina Mártir s/n, Cholula, 72810 Puebla, Mexico, carlos.ibarra@udlap.mx. 


\section{Introduction}

During the past two decades, a large empirical literature has applied the model of balance-of-payments-constrained growth (BPCG), originally developed by Thirlwall (1979), ${ }^{1}$ to a variety of countries and situations. In recent years, the model has been applied to countries as diverse as India (Razmi, 2005), China (Jeon, 2009), and Turkey (Halicioglu, 2012). A relatively new strand of the literature has sought to expand the model's compass to address comparative growth performance across global regions as well as structural changes within particular countries or regions (Cimoli et al., 2010). One branch of this new literature has developed a multisectoral version of “Thirlwall’s Law," which shows how changes in the sectoral composition of output can either relax or tighten the balance of payments (BP) constraint (Araujo and Lima, 2007; Gouvea and Lima, 2010).

One case in which the BPCG model appears to have had strong success is in explaining the growth slowdown in Mexico following its liberalization of trade in the late 1980s. MorenoBrid (1999, 2002), Pacheco-López and Thirlwall (2004), and several others (cited below) all found that Mexico’s income elasticity of import demand increased significantly during the postliberalization period (or after the formation of the North American Free Trade Agreement, NAFTA, in 1994), without a compensating acceleration of the country’s export growth. In the BPCG framework, this implies a reduction in the growth rate consistent with BP equilibrium, i.e., the growth rate just low enough to prevent chronically increasing trade deficits caused by imports rising faster than exports.

There is no question that Mexico’s average growth rate has declined since the country

\footnotetext{
${ }^{1}$ See McCombie and Thirlwall (2004), as well as other sources cited below, for later extensions and applications of this framework. For skeptical views, see Razmi (2011) and Ros (2012).
} 
opened its economy in the aftermath of the 1980s debt crisis. Mexico's growth rate has averaged about 3\% per year since 1987, barely half of what the country achieved between the 1940s and the 1970s. Similarly, the average growth rate of per capita income fell from about 3\% to 1\% per year between the same two periods (the gap is smaller in per capita terms because of slower population growth). ${ }^{2}$ However, the applications of the BPCG model to explaining this growth slowdown have mostly ignored crucial structural changes in Mexico's external trade between the pre- and post-liberalization eras.

In particular, the proportion of Mexico's imports that consists of intermediate goods has risen from about half in the pre-liberalization period to about two-thirds (excluding maquiladoras) or three-quarters (including them) in the post-liberalization period. Furthermore, manufactured exports, which are highly intensive in the use of imported intermediate inputs, have also risen to account for a majority of total exports in the same period (about two-thirds excluding maquiladoras, and four-fifths including them). ${ }^{3}$ According to the estimates of the multisectoral BPCG model in Gouvea and Lima (2010), Mexico’s exports shifted toward more technologically advanced products with higher income elasticities in a way that more resembles the East Asian countries rather than other Latin American nations in their sample. However, they do not take the heavy dependency of Mexican manufactured exports on imported intermediate goods into account in their modeling approach.

By neglecting potential differences in the behavior of imports of intermediate and final goods, econometric models that estimate aggregate import behavior may be misspecified and, in

\footnotetext{
${ }^{2}$ Data are from International Monetary Fund, International Financial Statistics and World Economic Outlook, online databases.

${ }^{3}$ The strong dependence of Mexican manufacturing on imported intermediate goods and the consequently low ratio of value added to the gross value of manufacturing output have been emphasized previously by other authors, including Ruiz-Nápoles (2004) and Moreno-Brid et al. (2005), but these authors mainly focused on other issues (such as employment generation) and did not incorporate intermediate imports into a BPCG modeling framework.
} 
particular, estimates of income elasticities may be biased. For example, what appears to be a rise in the income (GDP) elasticity of import demand may be, rather, a reflection of the increases in the shares of manufactured exports and intermediate imports in their respective totals. In this vein, Ibarra (2011a, 2011b) has shown that the income elasticity of Mexico’s demand for imports of intermediate goods did not increase significantly post-liberalization, once one controls for the fact that the demand for such imports is also a function of manufactured exports. However, Ibarra's work leaves open the question of whether the BP constraint on Mexico's growth was not tightened in another way, for example by an increase in the elasticity of intermediate imports with respect to manufactured exports.

Indeed, trade liberalization may have contradictory effects on BP-equilibrium growth: by facilitating imports of intermediate goods as well as access to foreign markets, it may boost the growth of manufactured exports; at the same time, however, the intensive use of intermediate imports in producing those exports diminishes the benefits in terms of relaxing the constraints on the rate of output growth consistent with BP equilibrium (hereafter, the "BP-equilibrium growth rate"). Overall, the net impact of trade liberalization on Mexico's BP-equilibrium growth rate is an empirical question that has yet to be resolved with a model that adequately incorporates the key role of intermediate imports in relation to the country's manufactured exports.

The present paper addresses this question by constructing a disaggregated BPCG model that incorporates two different kinds of imports (intermediate and final goods) and two different kinds of exports (manufactures and primary products). In this extended model, the solution for the BP-equilibrium growth rate takes account of the composition of imports and exports as well as the income elasticities and other estimated coefficients (especially, the elasticity of intermediate imports with respect to manufactured exports). 
Somewhat surprisingly, we find that, according to new econometric estimates of this model provided below, the BP-equilibrium growth rate did not decrease after Mexico liberalized its trade in the late 1980s, but instead actually increased. Although the income elasticity of the demand for imports of final goods did increase post-liberalization, neither the income elasticity of intermediate import demand nor the elasticity of this demand with respect to manufactured exports increased significantly. Furthermore, our estimates imply that Mexico grew faster than the rate predicted by our augmented BPCG model in the 1960s and 1970s, and has grown notably more slowly than the BPCG rate since the late 1980s. These results suggest that other factors, rather than a tightening of the BP constraint, have accounted for the post-liberalization slowdown in Mexican growth. These other factors may include indicators of external constraints more broadly defined (especially the real exchange rate, which is neglected in the standard BPCG approach), as well as various internal policies and obstacles.

Before proceeding further, two caveats are in order. First, as a result of limitations in the available data for the maquiladora sector, the econometric analysis in this paper is conducted using two alternative sets of measures of Mexico's manufactured exports and intermediate imports—one set including maquiladora data and one excluding them—and all the data series end in 2006. ${ }^{4}$ These two sets of data yield estimates that differ quantitatively in some significant (and intuitively reasonable) ways, but they yield qualitatively similar conclusions about whether a tightening of the BP constraint can explain Mexico’s post-liberalization growth slowdown. Second, the model used in this paper does not include capital flows or net transfers. However,

\footnotetext{
${ }^{4}$ Until 1979, Mexico did not include the maquiladora industries in its export and import statistics, and therefore maquiladora exports and imports prior to 1980 had to be estimated based on other available information (see appendix for details). In contrast, since 2007 Mexico has reported only total trade statistics including maquiladoras; separate data for maquiladoras are no longer reported so data series excluding them cannot be computed for those years. Therefore, for consistency, both sets of time series end in 2006, which still gives us adequate numbers of observations pre- and post-liberalization.
} 
this omission does not undermine our main results, and in fact strengthen them, because net transfers (primarily family remittances) and net capital inflows both increased (albeit modestly) as percentages of GDP during the post-liberalization period. ${ }^{5}$ Hence, if anything, the omission of these parts of the Mexican BP biases our results toward finding less of an increase (or more of a decrease) in the BP-equilibrium growth rate in the post-liberalization period.

The rest of the paper is organized as follows. Section 2 surveys the relevant literature. Section 3 presents the modified BPCG theoretical model. Section 4 discusses the data set and econometric estimates, while section 5 analyzes the implications of the results for the BPequilibrium growth rate as predicted by our modified BPCG model. Section 6 concludes with some thoughts on explaining the results and directions for future research.

\section{Literature survey}

Explanations for the slowdown in Mexico’s economic growth since the country liberalized its trade have generally fallen into two broad camps. On the one hand, based on the neoclassical focus on productive efficiency and supply-side factors, some economists have emphasized that reform of the domestic economy has lagged behind the liberalization of the external sector. In this view, the absence (or poor design) of reforms in areas such as fiscal policy, energy, telecommunications, labor markets, and the financial sector has put a drag on the country’s growth (e.g., Arias et al., 2010; Hanson, 2010; Kehoe and Ruhl, 2010; Walton and Levy, 2009). Neoclassical analysts have also focused on the slow rate of "total factor productivity” growth or alleged qualitative deficiencies of the country’s productive factors,

\footnotetext{
5 The average capital account balance (including the error component from the balance of payments) increased slightly, from 2.9\% of GDP (measured at the market exchange rate) during 1960-1986, to 3.2\% during 1987-2006. Net transfers also increased, from $0.6 \%$ to $1.6 \%$ of GDP between the same periods.
} 
especially relating to the educational level of the labor force and incentives for informalization (Arias et al., 2010; Kehoe and Ruhl, 2010). ${ }^{6}$ On the other hand, analyses informed more by a Keynesian emphasis on demand-side constraints have argued that the slow growth in the postliberalization era can be attributed to some combination of inadequate investment spending (especially deficient public spending on infrastructure), restrictive monetary and fiscal policies, an unequal distribution of income that limits the internal market, and various sorts of external constraints (Máttar et al., 2003; Galindo and Ros, 2008; Ibarra, 2008, 2010; Blecker, 2009; Moreno-Brid and Ros, 2009; Esquivel, 2010; Ros, 2010). The BPCG analysis can be seen as a special case of a Keynesian explanation focused on external constraints, which essentially claims that the opening to imports has outweighed the benefits of increased export growth, thus forcing the country to restrain the growth of its gross domestic product (GDP) to avoid large and growing current account deficits.

Given space constraints, we focus here on the studies that have emphasized external constraints in general and applications of the BPCG model in particular. Galindo and Ros (2008) showed that the inflation targeting policies of the Banco de México starting in the late 1990s have been applied in an asymmetrical manner that introduces a bias toward an overvalued peso. Ibarra $(2008,2010)$ showed that the real appreciation of the peso reduces the profit share in the Mexican manufacturing sector, and that this in turn has a negative effect on aggregate investment.

Blecker (2009) found that four external variables (the US growth rate, net financial inflows, real oil prices, and the one-year lagged real exchange rate) explain most of the annual fluctuations in Mexico’s growth during the period 1979-2007, with structural breaks in the

\footnotetext{
${ }^{6}$ For critical perspectives on these analyses, see Moreno-Brid and Ros (2009, pp. 231-251) and Hanson (2010).
} 
magnitude or significance of some of these effects after Mexico's initial trade liberalization (1987) or the enactment of NAFTA (1994). ${ }^{7}$ Also, many economists have found evidence that Chinese exports have significantly reduced or displaced Mexican exports since China joined the WTO in 2001, particularly in the US market (e.g., Gallagher et al., 2008; Hanson and Robertson, 2009; Feenstra and Kee, 2009). However, no one has connected this convincingly with Mexico’s long-run growth performance, which began to slow down before Chinese exports surpassed Mexican exports in the US market around 2001.

Applications of the BPCG model to Mexico began with Moreno-Brid (1998). The canonical form of this model can be expressed as follows. The export demand function, written in growth rate form, is

$$
x=\varepsilon_{x}\left(e+p^{*}-p\right)+\eta_{x} y^{*}
$$

where $x$ is the growth rate of exports, $e$ is the rate of nominal depreciation of the home currency, $p^{*}$ is the foreign inflation rate, $p$ is the home inflation rate, and $y^{*}$ is the growth rate of foreign real GDP. ${ }^{8}$ Thus, $e+p^{*}-p$ is the rate of change in the real exchange rate (RER) or rate of real depreciation, and $\varepsilon_{x}$ and $\eta_{x}$ are (respectively) the price (RER) and income elasticities of export demand (assumed to be constant for mathematical convenience). The import demand function is

$$
m=-\varepsilon_{m}\left(e+p^{*}-p\right)+\eta_{m} y
$$

where $m$ is the growth rate of imports, $y$ is the growth rate of home real GDP and $\varepsilon_{m}$ and $\eta_{m}$ are (respectively) the price (RER) and income elasticities of import demand, again assumed constant. Assuming no net capital flows, transfers, or net flows of factor income, balance of payments equilibrium in the long run requires that (in growth rate form)

\footnotetext{
${ }^{7}$ In particular, the impact of US growth only became significant post-NAFTA, while the effects of oil prices diminished and the effects of the real exchange rate increased post-liberalization.

${ }^{8}$ Note that exports are assumed to consist of the same goods as domestic output and hence sell at the same price.
} 


$$
p+x=e+p^{*}+m
$$

In the simplest version of the model, relative purchasing power parity (PPP) is assumed to hold in the long run, so $e+p^{*}-p=0$, in which case substitution of (1) and (2) into (3) yields the following well-known solution for the BP-equilibrium growth rate:

$$
y_{B}=\eta_{x} y^{*} / \eta_{m}=x / \eta_{m} .
$$

According to this model, trade liberalization increases (decreases) a country’s BPequilibrium growth rate if it raises the growth rate of exports proportionately more (less) than it increases the income elasticity of import demand. For the Mexican case, econometric studies by Moreno-Brid (1999, 2002), López and Cruz (2000), Guerrero de Lizardi (2003), Pacheco-López and Thirlwall (2004), Pacheco-López (2005), and Cardero and Galindo (2005) generally found that the income elasticity of import demand increased significantly post-liberalization (or postNAFTA), and that this increase outweighed the corresponding increase in export growth (which may be linked to an improvement in the foreign income elasticity of exports), leading to a decrease in the BP-equilibrium growth rate (4).

However, Ibarra (2011a, 2011b) argues that the standard BPCG model as specified above ignores an important feature of Mexico’s economic structure, which is the heavy dependence of its manufacturing sector (including export industries) on imports of intermediate inputs. There is therefore a direct connection between exports of manufactures and imports of intermediate goods that is missed in the standard analysis. Using data that exclude maquiladora trade, Ibarra (2011a) demonstrates that there is no statistically significant increase in the income elasticity of intermediate imports post-liberalization (1987-2006) compared with the pre-liberalization period (1960-1986), once the direct effect of manufactured exports is controlled for, and also that excluding the latter from the estimations results in a misspecified model. Similarly, Ibarra 
(2011b) shows that omitting the role of manufactured exports leads to an upward bias in estimates of the output elasticity of Mexico's intermediate imports for the post-liberalization period, using monthly trade data including maquiladoras for $1988-2006 .{ }^{9}$

These findings do not necessarily imply that there was no change in Mexico’s BPequilibrium growth rate after trade liberalization, however, because changes in other factors besides the income elasticity of intermediate import demand could have affected the country's BP constraint. Once one distinguishes different types of imports (intermediate versus final goods) and exports (manufactures versus primary products), one clearly needs a more complete BPCG model that can take differences in their behavior into account.

Recently, there has been some progress in developing multisectoral BPCG models applied to issues of structural change. Araujo and Lima (2007) and Gouvea and Lima (2010) have constructed a multisectoral version in which, fundamentally, the ratio of income elasticities $\left(\eta_{x} / \eta_{m}\right)$ in the solution (4) above is replaced by the ratio of trade-weighted averages of sectoral income elasticities of demand for exports and imports, thus allowing for an explicit role for structural changes in the composition of exports and imports to affect the BP-equilibrium growth rate. Applying this model to Mexico, Gouvea and Lima (2010) find that the ratio of the weighted income elasticities of exports to the weighted income elasticities of imports increased after trade liberalization in the late 1980s, more similar to the pattern in the East Asian countries than to the other Latin American nations in their sample. Although the authors only acknowledge the point obliquely, their analysis seems to imply that Mexico’s BP-equilibrium growth rate may have

\footnotetext{
${ }^{9}$ Because GDP is not available on a monthly basis, Ibarra (2011b) used an industrial production index as the output variable instead of GDP. Hence, we use the term "output" here instead of the more conventional "income" (which usually refers to GDP in an import demand function). Also, Ibarra (2011c) finds that there are no signs of foreign exchange pressure in the Mexican economy when growth accelerates and that investment does not respond strongly to variations in the level of foreign capital inflows, which shouldn't be the case under a binding external constraint.
} 
risen during the post-liberalization period, contrary to the earlier studies cited above. ${ }^{10}$ These authors also suggest that incorporating intermediate imports into the model might change this result when they write, "Mexico's export promotion efforts have not had a greater impact on the country's growth performance because of the high [intermediate] import content of its manufactured exports” (Gouvea and Lima, 2010, p. 188). However, they do not explicitly incorporate intermediate imports into their multisectoral BPCG model. Our analysis, below, will show that incorporating intermediate imports into a BPCG model (albeit an aggregative one) does not change the result that Mexico's BP-equilibrium growth rate increased in the postliberalization period. ${ }^{11}$

\section{A BPCG model with imports of intermediate goods}

This section presents a simple extension of the BPCG model that incorporates two different kinds of exports (manufactured and other goods) and two different kinds of imports (intermediate goods and final goods). All variables are expressed in growth rates (logarithmic differences) so that the coefficients can be interpreted as elasticities. The equations in log differences can be derived from underlying equations that are multiplicative in levels (the socalled "Cobb-Douglas" form, in which the parameters are exponents) or linear in log levels (in which case the exponents are converted to coefficients), which will be important to keep in mind

\footnotetext{
${ }^{10}$ The authors state that "the Latin American countries, except Mexico, have not changed the composition of their exports and imports in a way leading to higher BOPC [balance-of-payments-constrained] growth rates" (Gouvea and Lima, 2010, p. 186, emphasis added), implying that the BOPC growth rate did rise in Mexico after the late 1980s. However, the only explicit calculations of BP-equilibrium growth rates in their paper are for the entire sample period 1962-2006.

${ }^{11}$ Although we do not estimate a disaggregated model, we would note that the disaggregated model results in only a slight improvement over an aggregated model in the predictions for Mexico in Gouvea and Lima (2010, Table 2, p. 184). In any event, the data that would be required to separate out intermediate imports at the sectoral level on an annual basis do not exist, given the infrequent publication of input-output matrixes for Mexico.
} 
in regard to the econometric estimation in the next section.

The growth rate of demand for manufactured exports $\left(x_{n}\right)$, measured in the same units as domestic output, is determined by the function,

$$
x_{n}=\varepsilon_{n}\left(e+p^{*}-p\right)+\eta_{n} y^{*}
$$

where $e, p^{*}, p$, and $y^{*}$ are defined as before (except now $p^{*}$ and $p$ refer to inflation rates for prices of industrial goods only), and $\varepsilon_{n}$ and $\eta_{n}$ are the price and income elasticities for manufactured exports. For simplicity, we assume that other exports (primary commodities, chiefly oil and agricultural products, measured in their own physical units) grow at the exogenously given rate $x_{o}$, and their prices change at the exogenously given rate $p^{*}$ denominated in foreign currency (i.e., US dollars), presuming that their quantities and prices are determined by conditions in global commodity markets that are outside the scope of the present model.

The demand function for intermediate goods (in growth rate form) is given by

$$
m_{i}=-\varepsilon_{i}\left(e+p^{*}-p\right)+\eta_{i} y+\alpha x_{n}
$$

where the coefficient $\alpha$ is the elasticity of demand for imports of intermediate inputs with respect to manufactured exports. ${ }^{12}$ The demand function for imports of final (consumption and capital) goods (also in growth rate form, and with fairly obvious notation) is

$$
m_{c}=-\varepsilon_{c}\left(e+p^{*}-p\right)+\eta_{c} y
$$

where it is assumed that these imports are not a function of manufactured exports (as will be

\footnotetext{
${ }^{12}$ Note that the value of $\alpha$ depends on two factors, which are not modeled here explicitly. On the one hand, it depends on the underlying elasticity of imports of intermediate goods for use in export industries with respect to the production of manufactured exports. On the other hand, it depends on the proportion of intermediate goods imports that are devoted to export production (as opposed to domestic production). In principle, it would be desirable to model these two factors explicitly, which would require specifying the supply side of the model for production of exported and domestic manufactured goods. However, the available data do not distinguish intermediate goods imports according to whether they are used in the production of exported or domestic goods (except for the maquiladora industries, where it can be presumed that all imports are used in export production). Thus, the model as specified here is congruent with the data available for econometric estimation for the Mexican case.
} 
verified in the econometric estimates below). Imports are measured in units of foreign output.

Here we also assume, admittedly somewhat artificially, that all imports have the same prices and all import-competing domestic goods have the same prices, regardless of whether they are intermediate or final goods.

Again assuming no capital flows or transfers, the balance of payments equilibrium condition expressed in terms of foreign currency (US dollars) can be written (also in growth rate form) as

$$
\mu\left(p-e+x_{n}\right)+(1-\mu)\left(p_{o}^{*}+x_{o}\right)=\theta\left(p^{*}+m_{i}\right)+(1-\theta)\left(p^{*}+m_{c}\right)
$$

where $\mu$ is the share of manufactures in total exports and $\theta$ is the share of intermediate goods in total imports. Substituting (5), (6), and (7) into (8) and solving for the home country growth rate $y$, we obtain (after much manipulation):

$$
\begin{gathered}
y_{B}=\left[\theta \eta_{i}+(1-\theta) \eta_{c}\right]^{-1}\left\{(\mu-\alpha \theta) \eta_{n} y^{*}+(1-\mu)\left(p_{o}^{*}+x_{o}-p^{*}\right)\right. \\
\left.+\left[(\mu-\alpha \theta) \varepsilon_{n}+\theta \varepsilon_{i}+(1-\theta) \varepsilon_{c}-\mu\right]\left(e+p^{*}-p\right)\right\}
\end{gathered}
$$

which is the most general expression (under the above assumptions) for the BP-equilibrium growth rate $y_{B}$. Note that the term in brackets [·] multiplying the rate of RER depreciation $\left(e+p^{*}\right.$ $-p)$ would have to be positive, i.e., $(\mu-\alpha \theta) \varepsilon_{n}+\theta \varepsilon_{i}+(1-\theta) \varepsilon_{c}-\mu>0$, for a faster rate of real depreciation to increase the BP-equilibrium growth rate $y_{B}{ }^{13}$

If we assume that relative PPP prevails in the long run $\left(e+p^{*}-p=0\right)$, then (9) simplifies to:

$$
y_{B}=\frac{(\mu-\alpha \theta) x_{n}+(1-\mu)\left(p_{o}^{*}+x_{o}-p^{*}\right)}{\theta \eta_{i}+(1-\theta) \eta_{c}}
$$

\footnotetext{
${ }^{13}$ This condition can be thought of as an extended Marshall-Lerner condition for the present model. Note that this condition is stronger (i.e., more difficult to satisfy) than the standard Marshall-Lerner condition, to the extent that the weight ( $\mu-\alpha \theta$ ) on $\varepsilon_{x}$ is less than unity, although it is weaker (i.e., easier to satisfy) to the extent that $\mu<1$.
} 
where we use the fact that (from equation 5) $x_{n}=\eta_{x} y^{*}$ when $e+p^{*}-p=0$. To calculate $y_{B}$ in (10), we only need econometric estimates of equations (6) and (7) for imports of intermediate and final goods, respectively, in order to obtain estimates of the parameters $\alpha, \eta_{i}$, and $\eta_{c}$. On the assumption of long-run relative PPP, none of the coefficients in the manufactured export equation (5) are included in (10). All the other variables and parameters that go into the calculation of (10) can be obtained from the descriptive statistics.

The next section presents the estimates of equations (6) and (7), including tests for structural breaks after trade liberalization, while the following section reports the implications of those estimates for the BP-equilibrium growth rate $y_{B}$.

\section{Econometric estimates}

In this section we present estimation results for import demand equations in Mexico. ${ }^{14}$ As specified in equations (6) and (7), we provide separate estimates for imports of final (consumption and capital) goods and intermediate goods. Furthermore, as a result of issues of data availability for Mexico’s maquiladora sector, we also provide two sets of estimates for imports of intermediate goods: one using total imports of intermediate goods and exports of manufactures (including our own estimates of maquiladora imports and exports for years in which those were not reported), and one using imports of intermediate goods and exports of manufactured goods excluding maquiladoras. The latter data are obviously less inclusive, but they offer the advantage of being based entirely on officially reported statistics, and not requiring

\footnotetext{
${ }^{14}$ By estimating only import demand, we effectively assume that import supply curves are horizontal, i.e., we assume that Mexico is a "small country" in the sense of being a price-taker in its import markets. Fortunately, the econometric procedure used here helps to control for possible endogeneity of the RER and other right-hand-side variables, as discussed below. Also, the RER can be considered an exogenous instrument for the relative prices of imports and domestic goods, which would be more likely to be endogenous.
} 
any extrapolation of the data series. Moreover, although a more inclusive measure may seem superior, the combination of maquiladora and non-maquiladora imports of intermediate goods into a single aggregate combines two types of imports that may differ significantly in their behavior and determinants, as will be discussed further below. In any event, the two alternative sets of estimations, with and without maquiladoras included, provide a sensitivity test for the robustness of our results.

In standard fashion, imports are estimated as a function of real GDP and the bilateral peso-dollar real exchange rate (BRER), with an increase in the latter representing a real depreciation of the peso. For reasons of data availability, BRER was calculated with consumer price indices, rather than industrial prices as in the theoretical equations (6) and (7). In addition, to detect "long-run” effects, which are the relevant ones for the growth analysis in this paper, the variables in the estimated equations appear in levels (rather than growth rates as in the theoretical equations). All variables are expressed in levels of natural logarithms, so that their estimated coefficients can be interpreted as elasticities as required by the theoretical model. As is well known, using variables in differenced form loses information about long-run relationships, so we prefer to express the variables in (log) levels while using an econometric procedure (described below) that controls for possible unit roots in the variables. ${ }^{15}$

The estimation period runs from 1960 to 2006, for a total of 47 annual observations. It is not possible to conduct consistent estimations with a more updated sample, because the official statistics have not distinguished maquiladora and non-maquiladora trade flows since 2007. The estimations were carried out using the bounds testing approach of Pesaran et al. (2001), and the tables report only the estimated long-run (or level) coefficients plus the error-correction (or

\footnotetext{
${ }^{15}$ As observed earlier, although the theoretical model was presented with the variables expressed in log differences (growth rates), it can be derived from underlying equations that are linear in log levels, so we can use the latter specification for the econometric estimation.
} 
speed of adjustment) coefficient. ${ }^{16}$

The bounds testing approach has several attractive features. In contrast to alternative estimation procedures, it can combine variables with different orders of integration in the same equation; in particular, variables may be integrated of order one or zero. This is a critical advantage for our estimates, because the unit root tests reported in Table 1 indicate that our data include both types of series. ${ }^{17}$ In addition, none of the series is integrated of order two or more, as required by our estimation technique.

\section{[Table 1. Unit root tests]}

A second critical advantage is that, thanks to the use of lags in the estimation, the bounds testing approach yields unbiased estimates of the long-run coefficients even when some of the regressors are endogenous (Pesaran and Shin 1998)—a condition that presumably affects all macroeconomic series, including the ones used in this paper, to some extent. Finally, compared to data-intensive, multi-equation techniques such as Johansen’s vector error correction (VEC) model, the bounds testing approach has good small-sample properties, given that it relies on the estimation of a single equation.

The purpose of the estimation is to obtain equations of the form,

$$
M_{L R}=\delta_{0}+\delta_{1} Z_{1}+\delta_{2} Z_{2}+\ldots+\delta_{k} Z_{k}
$$

where $M_{L R}$ is the "long-run" level of real imports of either final or intermediate goods, there are $k$ potential determinants $Z_{i}$, and all variables are measured in log levels to capture long-run effects. To obtain equations like (11), we proceed in three steps. In the first step, we estimate an

\footnotetext{
16 The estimated short-run coefficients for the variables in first differences are not reported here for reasons of space, but are available on request.

${ }^{17}$ Both Phillips-Perron (PP) and Kwiatkowski-Phillips-Schmidt-Shinn (KPSS) tests show that BRER is stationary in levels or $I(0)$, while all other variables are stationary in first differences or $I(1)$. The PP test shows, rather anomalously, that real GDP is stationary in levels (as does an ADF test, not shown in the table), but the KPSS test (in which the null hypothesis is stationarity) shows that the null can be accepted at the 1\% level for real GDP.
} 
autoregressive distributed lag (ARDL) model in error-correction form, such as

$$
\Delta M_{t}=\sum_{j=1}^{n} a_{j} \Delta M_{t-j}+\sum_{i=1}^{k} \sum_{j=0}^{n} b_{i, j} \Delta Z_{i, t-j}+\sigma M_{t-1}+\sum_{i=1}^{k} d_{i} Z_{i, t-1}+d_{0}
$$

where $\Delta$ indicates the first difference of the variable, and $-\sigma$ measures the speed of adjustment of imports toward the long-run equilibrium defined by equation (11).

The dependent variable $M$ can be imports of either final goods (IMPF) or intermediate goods (IMPI excluding maquiladora imports, and IMPIM including them). The set of regressors $Z$ consists of three potential determinants: GDP, BRER, and real manufactured exports (EXPM excluding maquiladora exports, and EXPMM including them). The trade series, originally expressed in current dollars, were deflated with the US producer price index (PPI) to obtain real quantities of imports and exports, while GDP corresponds to Mexican output in constant pesos. BRER is based on consumer prices, and is defined so that an increase represents a real depreciation of the peso. ${ }^{18}$

Within the first step, we test the statistical adequacy of each model. This involves determining the number of lags to be included, and confirming that the standard diagnostic tests are satisfied. Based on the Schwarz and Akaike criteria, the models were estimated with one lag in the variables in first differences. The inclusion of one lag was sufficient to pass the standard battery of diagnostic tests, including the absence of serial correlation. In some cases the Akaike criterion suggested the inclusion of two lags, but in those cases Schwarz was followed, given the satisfactory diagnostic test results and the small number of observations in our sample. We verified that adding more lags did not result in stronger results for the bounds tests or a larger size of the speed of adjustment coefficient.

\footnotetext{
${ }^{18}$ See the appendix for more details on data sources and definitions, and the method of estimating maquiladora trade for the years with missing data.
} 
With the statistical adequacy of the model ensured, in a second step we test for the existence of a level or long-run relationship, using two alternative tests. The first is a $t$-test on the speed of adjustment coefficient, $\sigma$. For a long-run relationship to be established without ambiguity, the absolute value of the $t$-statistic must lie above the (asymptotic) upper critical value (or upper bound) calculated by Pesaran et al. (2001). In that case, the existence of a relationship can be accepted even if all the variables in the estimated equation were integrated of order one. In contrast, if the $t$-statistic falls between the lower and upper bound, then the existence of a relationship is more uncertain, as it can be accepted only conditional on all the variables being integrated of order zero (i.e., stationary). The second is an $F$-test for the significance of the level coefficients, under the null that $\sigma$ and the $d_{i}$ coefficients in equation (12) are jointly equal to zero. Again, the existence of a relationship is accepted when the F-statistic lies above the upper critical bound. For the $F$-test, we are able to use the small-sample critical values calculated by Narayan (2005), but for the sake of comparison we also report the results using the asymptotic critical values from Pesaran et al. (2001).

After establishing the existence of a long-run relationship, in a final step we simplify the short-run segment of the model. This is done by deleting, for each variable, the longest statistically insignificant lags (provided the diagnostic tests are not compromised). ${ }^{19}$ The simplification of the lag structure generally results in larger and more precisely estimated longrun coefficients. At the end of this step, we retrieve the long-run coefficients as $\delta_{i}=-d_{i} / \sigma$.

\footnotetext{
${ }^{19}$ This elimination of insignificant lags was not done in Ibarra (2011a). Hence, even though some of the estimates presented here are qualitatively similar to some of the ones in that paper, the present estimates are quantitatively different and have greater statistical precision. In addition, Ibarra (2011a) did not present equations for total imports of final goods (i.e., capital and consumption goods combined) or any estimates including maquiladora trade data.
} 


\subsection{Imports of final goods}

We begin by presenting the results for imports of final (consumption and capital) goods - "final imports” for short. In an initial specification we include only GDP and the real exchange rate as regressors, without allowing for a shift in coefficients after trade liberalization (Table 2, column 1). The estimated coefficients have the expected signs, indicating that an increase in GDP tends to raise final imports, while a real depreciation of the peso (that is, an increase in BRER) tends to reduce them. The estimated equation is not satisfactory, however: the coefficient on BRER is not statistically significant and the speed of adjustment $\sigma$ is very slow; in addition, the bounds tests reject the null hypothesis of no long-run relationship only under the condition that all variables are stationary—an unlikely condition, according to the results of the unit-root tests.

[Table 2. Estimated demand functions for imports of final goods]

Allowing for a permanent shift in the estimated coefficients on GDP and BRER after the beginning of trade liberalization dramatically improves the estimation results (Table 2, columns 2 and 3). Given that Mexico joined GATT in 1986, and that an important reduction in tariffs and in the share of import permits came afterwards, we examine whether a significant shift in the estimated coefficients took place beginning in 1987. For that purpose we define a dummy variable (DU87) that equals 1 in 1987-2006 (and 0 previously), and include interactions of this dummy with other variables in the import equations. We interact the dummy with both the level and the first difference of the import determinants, thus allowing for shifts in the long- and shortrun coefficients of the model. ${ }^{20}$

\footnotetext{
${ }^{20}$ In Ibarra (2011a), the structural break dummies were only interacted with the levels. This is another reason why the estimates in the present paper may differ from those earlier ones.
} 
Introducing the trade liberalization dummy leads to a much better model for final imports, particularly in terms of the bounds test results, which now support the existence of a long-run relationship at the $1 \%$ significance level. In this improved model, there are two main results. First, the real exchange rate coefficient appears to have become statistically significant only in the post-liberalization period. This is intuitive if we think that the composition of final demand may become more responsive to changes in the relative price of local versus imported goods, after restrictions on the free international flow of goods are removed. ${ }^{21}$ Second, there is a statistically significant increase in the income-elasticity of final imports, which rose from 1.10 during 1960-1986 to $1.56(=1.10+0.46)$ in 1987-2006 (Table 2, column 3).

Finally, we test for a potential role of manufactured exports, either including or excluding maquiladoras, in explaining final goods imports (Table 2, columns 4 and 5). We can see that manufactured exports, by either definition, have a coefficient that is not economically or statistically significant. Unsurprisingly, given this lack of significance, the introduction of this variable into the import equation leaves the previous results practically unchanged.

\subsection{Imports of intermediate goods, excluding and including maquiladoras}

We now present the estimated equations for imports of intermediate goods. Here, we have two sets of results: estimates excluding and including maquiladora data, which are shown in Tables 3 and 4, respectively. Starting with the results excluding maquiladoras, we again begin by showing a simple specification in which intermediate imports depend only on GDP and BRER (Table 3, column 1). As we found for final imports, in this initial specification the GDP and

\footnotetext{
${ }^{21}$ It should be noted, however, that we have not explicitly controlled for trade barriers such as tariff rates in any of the estimates in this paper. It could be that the RER was not a good measure of relative prices of traded goods during the pre-liberalization period, when such barriers were high.
} 
BRER coefficients have the expected signs, but again the results are not satisfactory: the $p$-value on the BRER coefficient is (slightly) above $10 \%$, the speed of adjustment is slow, and the bounds tests either fail to reject the null of no relationship, or reject it only conditional on all the variables being stationary; in addition, the RESET test for equation misspecification fails at the 5\% significance level.

[Table 3. Estimated demand functions for imports of intermediate goods excluding maquiladoras]

We then add manufactured exports as a possible determinant of intermediate imports (Table 3, column 2). There is a dramatic improvement: the speed of adjustment more than doubles, the two bounds tests (including the small-sample $F$-test) support the existence of a longrun relationship at the $5 \%$ level, and all the coefficients are statistically significant and signed as expected. While there is a reduction in the absolute values of the GDP and BRER coefficients, both are now statistically significant, and they are estimated with greater precision.

Compared with the estimated coefficient on GDP (1.01), the export coefficient is not small (0.51). How should we interpret the positive export coefficient? As mentioned in the theoretical section, the dependent variable corresponds to the economy's total intermediate imports (excluding only those used in the maquiladoras), and is not limited to those used in export production. In addition, the equation controls for GDP. Thus, the coefficient on EXPM measures the effect of an increase in manufactured exports holding GDP constant, which implies a shift in the composition of total output toward the export sector. Thus, the positive coefficient on exports means that export production is more intensive in intermediate imports than the rest of the economy, even excluding the maquiladoras, and consequently a pattern of GDP growth biased toward (or led by) manufactured exports will automatically result in strong import growth. 
Starting from this last specification, we test for structural breaks in the coefficients after the liberalization of trade. As we did for final imports, we include short- and long-run interactions of GDP and BRER with the DU87 liberalization dummy (Table 3, column 3). Once manufactured exports are included in the equation for intermediate imports, the GDP and BRER coefficients do not shift in the expected way in the post-liberalization period: rather than increasing, they decrease (in absolute value, in the case of the BRER coefficient). However, the bounds tests for this specification reject the null of no long-run relationship only under the condition of stationarity of all variables, so the results are not statistically reliable. Overall, once we control for the direct effect of manufactured exports, there is no evidence of an increase in the income elasticity of intermediate imports after trade liberalization.

Finally, we also examine whether the elasticity of intermediate imports with respect to manufactured exports ( $\alpha$, or the coefficient on EXPM) increased after trade liberalization. An increase could be expected, for example, from a deepening over time in the degree of vertical specialization in export production (even excluding maquiladoras, as we do here). To examine this issue, we include the interactive variable EXPM×DU87 (Table 3, column 4). Somewhat unexpectedly, there is no evidence of an increase in the EXPM coefficient after trade liberalization. ${ }^{22}$ The coefficient on EXPM $\times$ DU87 is very small and negative (-0.04); moreover, including this interactive variable reduces the significance of the bounds tests. Thus, the $p$-value of 0.03 for the estimated coefficient of -0.04 is not a reliable indicator of statistical significance, because the entire equation is not statistically adequate.

\footnotetext{
${ }^{22}$ Estimations using quarterly data for the liberalization period only suggest that an increase in the manufactured export-elasticity of intermediate imports may have occurred in the post-NAFTA years, especially when maquiladoras are included (Ibarra 2011b). However, using our annual data set for the sample period 1960-2006, we did not find a significant increase in this elasticity for the post-NAFTA years (1994-2006). This set of results is not shown here for reasons of space, but is available upon request.
} 
Next, we turn to the estimates that include maquiladora imports of intermediate goods and exports of manufactures (Table 4). Because these regressions are parallel to the ones we ran with the data excluding maquiladoras, our discussion can be shorter and focused on the key differences. When the regressors are limited to GDP and BRER (Table 4, column 1), only GDP is significant and its elasticity is very high (2.57). The insignificance of BRER is perhaps not surprising, since maquiladora imports of intermediate goods are so closely linked to maquiladora exports that they are likely to respond in the opposite direction from what we normally expect for imports to changes in BRER, rising when BRER increases (i.e., when the peso depreciates) as that would induce greater imports of intermediate goods for the assembly of increased exports of maquiladora products. Thus, mixing some imports that respond positively to BRER with others that respond negatively naturally lowers the estimated coefficient in absolute value and reduces its significance. In any event, this equation fails the bounds tests and so is not statistically reliable.

[Table 4. Estimated demand functions for imports of intermediate goods including maquiladoras] When we add manufactured exports including maquiladoras (EXPMM) as another regressor (Table 4, column 2), the equation passes the bounds tests at the $5 \%$ level, so the results may be deemed statistically reliable. Not surprisingly, the coefficient on manufactured exports is higher when maquiladora data are included than when they are excluded (0.71 vs. 0.51 ), and is strongly significant. The coefficient on BRER is larger in absolute value than in the equation omitting manufactured exports ( -0.53 vs. -0.19 ), but still statistically insignificant ( $p$-value of 0.17). Finally, the coefficient on GDP is now statistically significant, but much reduced in magnitude compared to the analogous estimate excluding maquiladoras (0.53 vs. 1.01). This is understandable because maquiladora imports of intermediate goods are largely unrelated to 
domestic Mexican production; rather, they are linked almost exclusively to export production.

When we test for structural breaks, we find similar results to those already obtained in the estimates for intermediate imports excluding maquiladoras (Table 4, columns 3 and 4). First, the existence of a long-run relationship can be accepted only on the unlikely condition that all variables are stationary. Second, the negative change in the GDP coefficient $(-0.25)$ suggests that the income elasticity of intermediate imports decreased after the liberalization of trade, which perhaps could be explained by the increasing importance of maquiladoras (whose demand for intermediate imports has little linkage to domestic output). Finally, the estimated change in the coefficient on manufactured exports is very small $(-0.03)$ and its negative sign is counterintuitive. On the whole, we conclude that there is no evidence of an increase in the elasticity of intermediate imports with respect to either income (GDP) or manufactured exports (EXPMM) when maquiladora data are included.

\section{Determination of the BP-equilibrium growth rate}

In this section, we calculate the BP-equilibrium growth rate $y_{B}$, as specified in equation (10) above, for the Mexican economy. For this purpose, we use the estimated elasticities from Table 2 (columns 1 and 3) for final imports ${ }^{23}$ and Tables 3 and 4 (column 2 in each) for intermediate imports, along with the requisite descriptive statistics from the underlying data set. The results are presented in Table 5, first for the entire period 1960-2006, and then separately for the pre- and post-liberalization periods, 1960-1986 and 1987-2006, respectively. As sensitivity

\footnotetext{
${ }^{23}$ It may be recalled that equation 1 in Table 2 rejects the null of no long-run relationship only conditional on all variables being integrated of order zero, which according to the unit root test results in Table 1 is unlikely to be the case. Nevertheless, these are the only coefficient estimates we have for imports of final goods over the whole sample period, so we use them in calculating $y_{B}$ for 1960-2006.
} 
tests, results are also presented for alternative time periods (1960-1977 and 1989-2006) that exclude the volatile years of the oil boom and debt crisis in 1978-1986, and for all time periods the results are presented both including and excluding maquiladoras.

[Table 5. Actual GDP growth compared with BP-equilibrium growth and its determinants] For the entire sample period 1960-2006, the BP-equilibrium growth rate of 4.01\% per year (excluding maquiladoras) or $4.36 \%$ (including maquiladoras) closely approximates the actual average GDP growth rate of 4.28\% per year (Table 5, first column). This conforms with previous studies that have found that the BPCG model closely replicates actual average growth rates over very long periods of time, on the order of a half century (e.g., Razmi, 2005, on India, as well as Gouvea and Lima, 2010, on Mexico).

The question that most concerns us here is whether the BPCG model can explain the slowdown in Mexico's growth since the trade liberalization of the late 1980s. The answer provided by our estimates is no. According to our calculations, Mexico's BP-equilibrium growth rate actually increased in the post-liberalization period (1987-2006) compared with the earlier years (1960-1986) — even more so when maquiladoras are included—whereas the actual average growth rate decreased notably (Table 5 , second and third columns). The increase in $y_{B}$ was the net effect of several different influences that operated in opposite directions after the liberalization of trade. On the one hand, there was an increase in the income-elasticity of final imports $\left(\eta_{c}\right)$, which tended to reduce $y_{B}$. On the other hand, the elasticities of intermediate imports with respect to GDP $\left(\eta_{i}\right)$ and manufactured exports $(\alpha)$ remained stable, regardless of whether maquiladoras were included or not. Moreover, the income elasticity of imports is lower for intermediate goods (1.01 excluding maquiladoras, 0.53 including them) than for final goods $\left(\eta_{c}\right)$, particularly in the post-liberalization period when this latter elasticity rose to 1.56 . As a 
consequence, the increase in the share of intermediate goods in total imports $(\theta)$, which rose from $49.1 \%$ in $1960-1986$ to $64.5 \%$ in $1987-2006$ excluding maquiladoras (or $52.3 \%$ to $75.5 \%$ including them), somewhat paradoxically tended to increase the BP-equilibrium growth rate by reducing the denominator in equation (10), where $\eta_{i}$ and $\eta_{c}$ are weighted by $\theta$ and $1-\theta$ respectively. ${ }^{24}$

Because the growth rate of manufactured exports $\left(x_{n}\right)$ was higher than the growth rate of other exports ( $x_{o}$, including terms-of-trade effects), the increase in the share of manufactures in total exports $(\mu)$ in the post-liberalization years (by either measure, including or excluding maquiladoras) had a positive effect on the BP-equilibrium growth rate. However, this positive effect was partly offset by the greater "leakage" of foreign exchange through imports of intermediate imports, as captured by the $-\alpha \theta$ term in (10). Although $\alpha$ did not increase, $\theta$ did, thus reducing the gains from any given rate of manufactured export growth (although of course the intensive use of intermediate imports undoubtedly contributed to the rapid growth of manufactured exports). Surprisingly, the growth rate of manufactured exports $x_{n}$ did not increase in the post-liberalization period, but rather fell slightly from 11.82\% per year in 1960-1986 to 10.45\% per year in 1987-2006 excluding maquiladoras (and from 13.95\% to 11.58\% including them). Of course, $10.45 \%$ (or $11.58 \%$ ) still represents a very rapid annual growth rate, but the growth of manufactured exports was even faster (by either measure) in the earlier period due to the very low base of such exports in the early 1960s.

Thus, there were various changes acting in different directions on the BP-equilibrium growth rate in the post-liberalization period. The net impact was that the BP-equilibrium GDP

\footnotetext{
${ }^{24}$ However, the post-liberalization rise in $\theta$ had two opposite effects on $y_{B}$ per equation (10), as it tended to reduce both the numerator (via the $-\alpha \theta$ term) and the denominator (by increasing the weight on $\eta_{i}<\eta_{c}$ ). Under the parameter values prevailing in the post-liberalization period, it is easily calculated that the net effect of the rise in $\theta$ on $y_{B}$ was negative, i.e., the effect on the numerator dominates.
} 
growth rate actually increased after trade liberalization, rising from 4.2\% during 1960-1986 to $4.7 \%$ in $1987-2006$ excluding maquiladoras, or $4.3 \%$ to $5.5 \%$ including them. Furthermore, although the actual and BP-equilibrium GDP growth rates were similar over the entire period (especially when maquiladora trade is included), they differ notably within each of the two subperiods. During the pre-liberalization period, the actual GDP growth rate was above the BPequilibrium rate ( $5.2 \%$ versus $4.2 \%$ excluding maquiladoras or $4.3 \%$ including them), while the opposite was true during the post-liberalization period (3.0\% versus $4.7 \%$ excluding maquiladoras or 5.5\% including them). Thus, during the post-liberalization period the Mexican economy has underperformed, at least relative to its BP constraint, and this constraint does not appear to have been binding. Qualitatively similar results are obtained if we omit the years of the oil boom of the late 1970s and the debt crisis of the 1980s, and define the pre- and postliberalization periods as 1960-1977 and 1989-2006, respectively, except by this definition the gap between the actual and BP-equilibrium growth rates is even greater for the pre-liberalization period (Table 5, last two columns).

\section{Conclusions and directions for future research}

This paper has developed an extended BPCG model, which incorporates two kinds of exports (manufactured and other) and two kinds of imports (intermediate and final goods). According to our estimates, the BP-equilibrium growth rate closely fits the actual, average growth of Mexico’s GDP during the 47-year period from 1960 to 2006. As in most previous studies, the model accounts for actual growth well in very long-run samples, on the order of a half century. In contrast, there are large differences between the actual and the BP-equilibrium 
growth rate in each of our two sub-periods (pre- and post-liberalization). The sign of those differences suggests that the BP constraint was binding in the first of those periods, and therefore the actual rates of growth could not be sustained, while in the second period the BP constraint was not binding and thus the fall in actual GDP growth must be attributed to other factors.

Thus, according to our estimates, Mexico outperformed its BP-equilibrium growth during the pre-liberalization years 1960-1986, and even more strongly so if we omit the oil boom and debt crisis years and consider only 1960-1977. This finding is consistent with the fact that, by the end of the pre-liberalization period, Mexico was facing a series of repeated balance of payments crises that resulted in the sharp peso devaluations of 1975-1976, 1982-1983, and 1985-1986 (crises that can perhaps be seen as having imposed a BP constraint after episodes in which it was violated).

In contrast, the estimates in this paper do not support the hypothesis that a tightening of the balance of payments constraint can account for the slowdown of Mexico's economic growth in the post-liberalization years. On the contrary, our estimates show that the BP-equilibrium growth rate actually increased in the post-liberalization period, especially when maquiladora trade data is included (but also, albeit to a lesser extent, when they are omitted), suggesting that liberalization was modestly successful in relieving the country's previous BP constraint, and certainly did not tighten it.

Because the actual average growth of the Mexican economy fell substantially in the postliberalization period, our estimates imply that the Mexican economy has been underperforming relative to its BP-equilibrium growth rate during this period — and the more so, if we include the maquiladora sector, which was one of the most dynamic parts of the Mexican economy especially during the late 1980s and 1990s. There are several possible explanations for this 
underperformance. First, as in most previous studies in the BPCG framework, we have ignored changes in the RER and focused on income elasticities (which, in this paper, are augmented by the elasticity of intermediate imports with respect to manufactured exports). Similar to some earlier work in this framework (e.g., Perraton, 2003), we have allowed for terms-of-trade effects in regard to primary commodity exports, but not RER effects for manufactured exports and imports. Our BRER index ${ }^{25}$ shown in Figure 1, was relatively constant in the very long run, in the sense that there is no pronounced trend over the entire sample period 1960-2006. The average levels of BRER were similar during the split sample periods, pre- and postliberalization, and the average rate of change over the whole period 1960-2006 $(-0.25 \%$ per year) was very small. This may help to account for why the model's prediction for the BPconstrained growth rate closely approximates the actual average growth rate over the entire 47year sample period.

[Figure 1. Bilateral Mexican-US real exchange rate index, 1960-2006]

The trajectories of the RER were very different, however, within the pre- and postliberalization periods considered separately. During the 1960s, the BRER index (which is based on 100 in 1996, and reflects the value of the peso inversely) was relatively stable, with an index value of about 84, and then it decreased (i.e., the peso appreciated) in two episodes during the 1970s — both of which were followed by currency crises and sharp devaluations. After the debt crisis of the early 1980s, BRER soared to 127 in 1986, so that the overall trend during the preliberalization period 1960-1986 was toward a real depreciation. After liberalization, there was a reversal of this trend, with a tendency for the peso to appreciate (in spite of one more maxidevaluation in 1994-1995), and the BRER index fell to 78 in 2006.

\footnotetext{
${ }^{25}$ In this discussion, we deliberately use "RER" when referring to the real exchange rate in general and "BRER" when referring specifically to our bilateral index.
} 
The tendency of the peso to appreciate in real terms in the post-liberalization period may have been an important factor in the underperformance of the Mexican economy during that time. ${ }^{26}$ This suggests that further modification of the BPCG model to take account of RER fluctuations may be important for explaining the post-liberalization slowdown in Mexico’s growth. Whether incorporating the RER improves the predictive power of the model can be tested in future research by estimating equation (5) for Mexico’s manufactured exports, and then using equation (9), which includes the price (RER) elasticities, instead of (10), which excludes them, to calculate $y_{B} \cdot{ }^{27}$ Although an explanation of the growth slowdown that relies upon relative price (RER) changes would be consistent with a BP constraint in a broader sense, it would be different from the traditional BPCG model in which relative prices are assumed to have no impact.

However, it is possible that no extension of the BPCG model will suffice to enable this framework to explain the post-liberalization growth slowdown in Mexico. In this case, it would be important to identify the other factors that could account for that slowdown. For example, the financial and fiscal constraints referred to earlier, which have depressed the nation's investment rate (both private and public), could be prime suspects. The RER could also play an additional role, as a real appreciation may squeeze profit margins in the tradables sector and discourage private investment (see Ibarra 2008, 2011c). Supply-side factors, such as financial sector

\footnotetext{
${ }^{26}$ Although the average level of the real exchange rate was similar in our two sub-periods, trade liberalization may have required a more depreciated level of the currency to sustain a given rate of economic growth under the new conditions of reduced tariff and non-tariff protection for domestic firms. Thus, while the real exchange rate shows similar average levels pre- and post-liberalization, it is possible that the real exchange rate was misaligned in the latter but not in the former sub-period.

${ }^{27}$ Of course, any explanation that focuses on RER changes would require that the price (RER) elasticities of export and import demand were sufficiently large (in absolute value) to satisfy the (modified) Marshall-Lerner condition embedded in the model (see the discussion of equation 9 and footnote 13 above). In the preceding estimates, the RER elasticity of final imports becomes significant only after liberalization (Table 2, columns 3-5), while the RER elasticity of intermediate imports (excluding maquiladoras) becomes smaller in absolute value post-liberalization, so our own results are mixed. See also Ibarra (2011a, 2011b) for earlier estimates of the relative price (RER) elasticities of Mexican import demand and how they compare with previous estimates in the literature.
} 
rigidities, rule of law, monopoly control of key industries, and deficiencies in human capital formation, could also possibly play a role. One important hypothesis to consider is that the changes in macroeconomic policy since the 1990s—especially, the strict inflation-targeting monetary policy and balanced-budget targets for fiscal policy—may have led to a situation in which the country's actual growth is chronically held below its potential or BP-equilibrium rate. Such possibilities will have to be explored in future research. 


\section{Appendix. Data sources and definitions}

Bilateral real exchange rate (BRER): Calculated as the ratio of the consumer price index (CPI) of Mexico to the US CPI, multiplied by the nominal peso-dollar exchange rate. Sources: US Bureau of Labor Statistics (BLS) for the US consumer price index, the IMF's International Financial Statistics for Mexico's CPI and nominal exchange rate from 1960 to 1967, and Banco de México (BOM) for the same variables since 1968.

Gross domestic product (GDP): In constant prices of 1993 for 1980-2006; pre-1980 data were based on constant prices of 1980 and were spliced with the later data. Source: National accounts data from Mexico’s Instituto Nacional de Estadística y Geografía (INEGI).

Imports of final goods and intermediate goods: Final goods imports (IMPF) are the sum of consumption and capital goods. Intermediate goods were calculated two alternative ways, including maquiladoras (IMPIM) and excluding them (IMPI); see below regarding maquiladora data. The original BP data, in nominal dollars, were deflated with the general US PPI for finished goods. Source: BOM for trade data, and BLS for price index.

Manufactured exports: Calculated two alternative ways, including maquiladoras (EXPMM) and excluding them (EXPM); see below regarding maquiladora data. The original BP data, in nominal US dollars, were deflated with the general US PPI for finished goods. Source: BOM for trade data, and BLS for price index.

Non-manufactured exports: Calculated as the difference between total exports of goods and manufactured exports. The original BP data, in nominal US dollars, were deflated with the general US PPI for finished goods. Source: BOM for trade data, and BLS for price index.

Maquiladora exports and imports: For 1980-2006, Mexico reported export and import data excluding maquiladoras, but data for maquiladora exports and imports were also reported separately, so the latter were added to the officially reported data for manufactured exports and intermediate imports (respectively) to obtain total manufactured exports and total intermediate imports. For the years prior to 1980, we were not able to find data for maquiladora exports or imports, but Mexico did include a line for services of transformation (i.e., maquiladora value added) as a credit item in the current account of the balance of payments (data from BOM). For 1969-1979, we used US data for imports from Mexico under tariff sections 806.300 and 807.00 (from Grunwald, 1985, p. 148, Table 4-6) for maquiladora exports (assuming that virtually all maquiladora exports were sold in the United States in those years), and then subtracted maquiladora value added to get maquiladora imports (value added for 1979 was interpolated). For 1966-1968, we assumed that maquiladora exports were in the same ratio to value added as the average for 1969-1970 (2.76), and then subtracted value added from exports to get imports. We could not find any data on maquiladora value added for 1965, the year when the maquiladora program was enacted by the Mexican government, so we assumed that maquiladora exports and imports were zero in that year (if this is not accurate, the number for 1966 is so low that it must have been negligible in 1965). All these data were measured in US dollars and converted to real terms using the US PPI for finished goods. 


\section{References}

Araujo, R.A., Lima, G.T., 2007. A structural economic dynamics approach to balance-ofpayments-constrained growth. Cambridge Journal of Economics 31, 755-774.

Arias, J., Azuara, O., Bernal, P. Heckman, J.J., Villarreal, C., 2010. Policies to Promote Economic Growth and Efficiency in Mexico. Institute for the Study of Labor (IZA), Bonn.

Blecker, R.A., 2009. External shocks, structural change, and economic growth in Mexico, 19792007. World Development 37, 1274-1284.

Cardero, M.E., Galindo, L.M., 2005. From the import substitution model to the import-export model: reassessing Mexico’s trade liberalization process during the last two decades. Journal of Economic Asymmetries 2, 71-97.

Cimoli, M., Porcile, G., Rovira, S., 2010. Structural change and the BOP-constraint: why did Latin America fail to converge? Cambridge Journal of Economics 34, 389-411.

Esquivel, G., 2010. De la inestabilidad macroeconómica al estancamiento estabilizador: el papel del diseño y conducción de la política económica. In: Lustig, N. (Ed), Los Grandes Problemas de México, vol. 9, Crecimiento Económico y Equidad. El Colegio de México, Mexico City, pp. 35-77.

Feenstra, R.C., Kee, H.L., 2009. Trade liberalization and export variety: a comparison of Mexico and China. In Lederman, D., Olarreaga, M., Perry, G.E. (Eds.), China’s and India’s Challenge to Latin America. World Bank, Washington, pp. 245-263.

Galindo, L.M., Ros, J., 2008. Alternatives to inflation targeting in Mexico. International Review of Applied Economics 22, 201-214.

Gallagher, K.P., Moreno-Brid, J.C., Porzecanski, R., 2008. The dynamism of Mexican exports: lost in (Chinese) translation? World Development 36, 1365-1380.

Gouvea, R.R., Lima, G.T., 2010. Structural change, balance-of-payments-constraint, and economic growth: evidence from the multisectoral Thirlwall's law, Journal of Post Keynesian Economics 33, 169-204.

Grunwald, J., 1985. The assembly industry in Mexico. In: Grunwald, J., Flamm, K. (Eds.), The Global Factory: Foreign Assembly in International Trade. Brookings, Washington, pp. 137179.

Guerrero de Lizardi, C., 2003. Modelo de crecimiento restringido por la balanza de pagos: evidencia para México, 1940-2000. El Trimestre Económico 70, 253-273.

Halicioglu, F., 2012. Balance-of-payments-constrained growth: the case of Turkey. Journal of Post Keynesian Economics 35, 65-77.

Hanson, G., 2010. Why Mexico isn’t rich. Journal of Economic Literature 48, 987-1004. 
Hanson, G.H., Robertson, R., 2009. China and the recent evolution of Latin America's manufacturing exports. In: Lederman, D., Olarreaga, M., Perry, G.E. (Eds.), China’s and India’s Challenge to Latin America. World Bank, Washington, pp. 145-178.

Ibarra, C.A., 2008. Mexico’s slow growth paradox. CEPAL Review, No. 95, 83-102.

Ibarra, C.A., 2010. Exporting without growing: investment, real currency appreciation, and export-led growth in Mexico. Journal of International Trade and Economic Development 19, 439-464.

Ibarra, C.A., 2011a. A note on intermediate imports and the BPCG model in Mexico. Economic Change and Restructuring 44, 357-368.

Ibarra, C.A., 2011b. Import elasticities and the external constraint in Mexico. Economic Systems $35,363-377$.

Ibarra, C.A., 2011c. Capital flows, real exchange rate, and growth constraints in Mexico. International Review of Applied Economics 25, 653-668.

Jeon, Y., 2009. Balance-of-payment constrained growth: the case of China, 1979-2002. International Review of Applied Economics 23, 135-146.

Kehoe, T., Ruhl, K.J., 2010. Why have economic reforms in Mexico not generated growth? Journal of Economic Literature 48, 1005-1027.

Kwiatkowski, D., Phillips, P.C.B., Schmidt, P., Shin, Y., 1992. Testing the null hypothesis of stationary against the alternative of a unit root. Journal of Econometrics 54, 159-178.

López, J., Cruz, A., 2000. Thirlwall's law and beyond: the Latin American experience. Journal of Post Keynesian Economics 22, 477-495.

Máttar, J., Moreno-Brid, J.C., Peres, W., 2003. Foreign investment in Mexico after economic reform. In: Middlebrook, K.J., Zepeda, E. (Eds.), Confronting Development: Assessing Mexico's Economic and Social Policy Challenges. Stanford University Press, Stanford, CA, pp. 123-160.

McCombie, J.S.L., Thirlwall, A.P. (Eds.), 2004. Essays on Balance of Payments Constrained Growth: Theory and Evidence. Routledge, London.

Moreno-Brid, J.C., 1998. Balance-of-payments constrained economic growth: the case of Mexico. Banca Nazionale del Lavoro Quarterly Review, No. 207, 413-433.

Moreno-Brid, J.C., 1999. Mexico's economic growth and the balance of payments constraint: a cointegration analysis. International Review of Applied Economics 13, 149-159.

Moreno-Brid, J.C., 2002. Liberalización comercial y la demanda de importaciones en México. Investigación Económica 62, 13-51. 
Moreno-Brid, J.C., Ros, J., 2009. Development and Growth in the Mexican Economy: A Historical Perspective. Oxford University Press, Oxford.

Moreno-Brid, J.C., Santamaría, J., Rivas Valdivia, J.C., 2005. Industrialization and economic growth in Mexico after NAFTA: the road travelled. Development and Change 36, 10951119.

Narayan, P.K., 2005. The saving and investment nexus for China: evidence from cointegration tests. Applied Economics 37, 1979-1990.

Pacheco-López, P., 2005. The impact of trade liberalization on exports, imports, the balance of trade, and growth: the case of Mexico. Journal of Post Keynesian Economics 27, 595-619.

Pacheco-López, P., Thirlwall, A.P., 2004. Trade liberalisation in Mexico: rhetoric and reality,” Banca Nazionale del Lavoro Quarterly Review, No. 229, 141-167.

Perraton, J., 2003. Balance of payments constrained growth and developing countries: an examination of Thirlwall's hypothesis. International Review of Applied Economics 17, 1-22.

Pesaran, M.H., Shin, Y., 1998. An autoregressive distributed-lag approach to cointegration analysis. In: S. Strom (Ed), Econometrics and Economic Theory in the 20th Century. Cambridge University Press, New York, pp. 371-413.

Pesaran, M. H., Shin, Y., Smith, R. J., 2001. Bounds testing approaches to the analysis of level relationships. Journal of Applied Econometrics 16, 289-326.

Razmi, A., 2005. Balance of payments constrained growth model: the case of India. Journal of Post Keynesian Economics 27, 655-687.

Razmi, A., 2011. Exploring the robustness of the balance of payments-constrained growth idea in a multiple good framework. Cambridge Journal of Economics 35, 545-567.

Ros, J., 2010. Política fiscal, tipo de cambio y crecimiento en regímenes de alta y baja inflación: la experiencia de México. In: Lustig, N. (Ed), Los Grandes Problemas de México, vol. 9, Crecimiento Económico y Equidad. El Colegio de México, Mexico City, pp. 109-132.

Ros, J., 2012. Growth, Effective Demand, and Factor Accumulation. Manuscript, UNAM, Mexico City.

Ruiz-Nápoles, P., 2004. Exports, growth, and employment in Mexico, 1978-2000. Journal of Post Keynesian Economics 27, 105-124.

Thirlwall, A.P., 1979. The balance of payments constraint as an explanation of international growth rate differences. Banca Nazionale del Lavoro Quarterly Review. No. 128, 45-53.

Walton, M., Levy, S. (Eds.), 2009. No Growth without Equity? Inequality, Interests, and Competition in Mexico. World Bank, Washington. 
Table 1

Unit root tests (sample period: 1960-2006; 47 annual observations).

\begin{tabular}{|c|c|c|c|c|c|c|}
\hline & \multicolumn{3}{|c|}{$\begin{array}{c}\text { Phillips-Perron } \\
\text { (PP) } \\
\text { Null: unit root } I(1)^{\mathrm{a}} \\
\end{array}$} & \multicolumn{3}{|c|}{$\begin{array}{c}\text { Kwiatkowski, Phillips, } \\
\text { Schmidt, and Shinn (KPSS) } \\
\text { Null: stationary I(0) }\end{array}$} \\
\hline & level & $\begin{array}{l}\text { level with } \\
\text { trend }\end{array}$ & $\begin{array}{c}\text { first } \\
\text { difference }\end{array}$ & level & $\begin{array}{l}\text { level with } \\
\text { trend }\end{array}$ & $\begin{array}{c}\text { first } \\
\text { difference } \\
\end{array}$ \\
\hline Bilateral real exchange rate, BRER & $-2.90 *$ & -2.87 & $-8.00 * * *$ & $0.118 \dagger$ & $0.111 \dagger$ & $0.184 \dagger$ \\
\hline Gross domestic product, GDP & $-3.25 * *$ & -1.55 & $-4.71 * * *$ & 0.863 & 0.216 †† & $0.537 \dagger \dagger \dagger$ \\
\hline Imports of intermediate goods excl. maquiladoras, IMPI & -0.42 & -2.62 & $-6.57 * * *$ & 0.864 & $0.072 \dagger$ & $0.081 \dagger$ \\
\hline Imports of intermediate goods incl. maquiladoras, IMPIM & -0.35 & -2.55 & $-6.07 * * *$ & 0.871 & $0.071 \dagger$ & $0.076 \dagger$ \\
\hline Manufactured exports excl. maquiladoras, EXPM & -1.11 & -2.86 & $-6.92 * * *$ & 0.881 & $0.070 \dagger$ & $0.101 \dagger$ \\
\hline Manufactured exports incl. maquiladoras, EXPMM & -1.62 & -2.28 & $-6.80 * * *$ & 0.880 & $0.088 \dagger$ & $0.199 \dagger$ \\
\hline
\end{tabular}

Notes: All variables are measured in natural logarithms (GDP, imports, and exports in real terms). See appendix for data sources and variable definitions. All tests assume an intercept and use the Bartlett kernel and Newey-West bandwidth.

a $* * *, * *, *$ : The null hypothesis of a unit root is rejected at the $1 \%, 5 \%, 10 \%$ significance levels, using MacKinnon one-sided $p$-values for PP.

$\mathrm{b}+\dagger \dagger, \uparrow \dagger, \uparrow$ : The null hypothesis of stationarity is accepted at the 1\%, 5\%, 10\% significance level. Critical values from Kwiatkowski, Phillips, Schmidt, and Shinn (1992,

Table 1): For level or first difference, $10 \%=0.347 ; 5 \%=0.463 ; 1 \%=0.739$. For level with trend, $10 \%=0.119 ; 5 \%=0.146 ; 1 \%=0.216$. 
Table 2

Estimated demand functions for imports of final goods (dependent variable: IMPF; sample period: 1960-2006, 47 annual observations).

\begin{tabular}{|c|c|c|c|c|c|}
\hline & $(1)^{\mathrm{a}}$ & $(2)$ & (3) & (4) & (5) \\
\hline \multicolumn{6}{|l|}{ Long-run coefficients: } \\
\hline Speed of adjustment, $\sigma$ & -0.102 & -0.161 & -0.231 & -0.243 & -0.251 \\
\hline Gross domestic product, GDP & $1.58(0.02)$ & $1.24(0.00)$ & $1.10(0.00)$ & $1.19(0.00)$ & $1.12(0.00)$ \\
\hline Real exchange rate, BRER & $-1.24(0.19)$ & $-0.54(0.19)$ & & & \\
\hline Manufactured exports excl. maquiladoras, EXPM & & & & $-0.09(0.46)$ & \\
\hline Manufactured exports incl. maquiladoras, EXPMM & & & & & $-0.03(0.69)$ \\
\hline GDP×DU87 & & $0.15(0.00)$ & $0.46(0.00)$ & $0.54(0.01)$ & $0.62(0.00)$ \\
\hline $\mathrm{BRER} \times \mathrm{DU} 87$ & & & $-1.17(0.02)$ & $-1.39(0.02)$ & $-1.66(0.01)$ \\
\hline \multicolumn{6}{|l|}{ Diagnostics: $^{\mathrm{b}}$} \\
\hline Adjusted $R^{2}$ & 0.831 & 0.934 & 0.962 & 0.961 & 0.963 \\
\hline Jarque-Bera & $0.34(0.84)$ & $1.61(0.45)$ & $0.27(0.87)$ & $0.11(0.95)$ & $1.80(0.41)$ \\
\hline Breusch-Godfrey & $0.35(0.56)$ & $0.33(0.57)$ & $0.13(0.72)$ & $0.09(0.76)$ & $0.40(0.53)$ \\
\hline $\mathrm{ARCH}$ & $0.08(0.77)$ & $0.74(0.39)$ & $0.00(0.99)$ & $0.03(0.85)$ & $0.09(0.77)$ \\
\hline RESET & $0.00(0.98)$ & $2.83(0.10)$ & $0.09(0.76)$ & $0.24(0.63)$ & $0.80(0.38)$ \\
\hline \multicolumn{6}{|l|}{ Bounds testing: ${ }^{\mathrm{C}}$} \\
\hline$t$-stat & $-2.62^{\mathrm{d}}$ & $-5.24 * * *$ & $-6.28 * * *$ & $-5.57 * * *$ & $-5.52 * * *$ \\
\hline$F$-stat & $3.06^{\mathrm{e}}$ & $13.62 * * *(+++)$ & $16.88 * * *(+++)$ & $11.70 * * *(+++)$ & $13.08 * * *(+++)$ \\
\hline
\end{tabular}

Notes: For illustrative purposes, the $p$-values of the $d_{i}$ coefficients (see equation 12 in the text) are shown in parenthesis next to the long-run coefficients. The intercept was removed from all equations due to lack of significance. The ARDL models were estimated initially with one lag for the variables in first differences. The estimation results shown in the table correspond to the models after the longest non-statistically significant coefficients were removed, except the results of bounds testing, which was performed with the full lag structure.

a To pass the normality test, eq. (1) includes a 0-1 dummy for the year 1975, while the rest of equations also include dummies for 1986 , 1987 , and 1993.

$\mathrm{b}$ The null hypotheses are that residuals are normally distributed (Jarque-Bera), with no serial correlation of first order (Breusch-Godfrey) and no ARCH errors, and that the equation passes Ramsey's mis-specification test using the squares of the fitted values (RESET). F-statistics (except $\chi^{2}$ for J-B) with $p$-values in parenthesis.

${ }^{c}$ For bounds tests: $* * *, * *, *$ signify rejects the null of no level relationship at the $1 \%, 5 \%, 10 \%$ significance levels, using the asymptotic upper critical values from Pesaran et al. (2001), tables CI(i) and CII(i): no intercept and no trend. +++, ++, +: Rejects the null of no level relationship at the $1 \%$, 5\%, 10\% significance level, using the small-sample upper critical values from Narayan (2005), appendix case II: restricted intercept and no trend, for $n=45$ observations. Critical values are available only for the $F$-test.

${ }^{\mathrm{d}}$ Rejects the null of no level relationship at $1 \%$ only under the condition that all variables are integrated of order zero.

${ }^{\mathrm{e}}$ Rejects the null of no level relationship, at 5\% with the asymptotical critical values from Pesaran et al. and at 10\% with the small-sample critical values from Narayan, only under the condition that all variables are integrated of order zero. 
Table 3

Estimated demand functions for imports of intermediate goods excluding maquiladoras (dependent variable: IMPI; sample period: 1960-2006, 47 annual observations).

\begin{tabular}{|c|c|c|c|c|}
\hline & $(1)$ & $(2)$ & (3) & $(4)$ \\
\hline \multicolumn{5}{|l|}{ Long-run coefficients: } \\
\hline Speed of adjustment, $\sigma$ & -0.109 & -0.260 & -0.244 & -0.272 \\
\hline Gross domestic product, GDP & $1.90(0.05)$ & $1.01(0.00)$ & $0.79(0.05)$ & $0.68(0.06)$ \\
\hline Real exchange rate, BRER & $-2.05(0.11)$ & $-1.36(0.00)$ & $-1.35(0.02)$ & $-1.09(0.01)$ \\
\hline Manufactured exports excl. maquiladoras, EXPM & & $0.51(0.01)$ & $0.73(0.00)$ & $0.75(0.00)$ \\
\hline GDP×DU87 & & & $-0.37(0.05)$ & \\
\hline BRER $\times$ DU87 & & & $1.06(0.06)$ & \\
\hline $\mathrm{EXPM} \times \mathrm{DU} 87$ & & & & $-0.04(0.03)$ \\
\hline \multicolumn{5}{|l|}{ Diagnostics: } \\
\hline Adjusted $R^{2}$ & 0.676 & 0.802 & 0.830 & 0.821 \\
\hline Jarque-Bera & $0.34(0.84)$ & $1.01(0.60)$ & $1.15(0.56)$ & $1.32(0.52)$ \\
\hline Breusch-Godfrey & $0.37(0.55)$ & $0.22(0.64)$ & $0.57(0.45)$ & $0.06(0.81)$ \\
\hline $\mathrm{ARCH}$ & $0.38(0.54)$ & $1.03(0.31)$ & $0.03(0.86)$ & $0.02(0.90)$ \\
\hline RESET & $4.79(0.03)$ & $0.10(0.76)$ & $0.22(0.64)$ & $0.07(0.79)$ \\
\hline \multicolumn{5}{|l|}{ Bounds testing: } \\
\hline$t$-stat & $-2.16^{\mathrm{a}}$ & $-3.49 * *$ & $-3.18^{\mathrm{a}}$ & $-3.40 *$ \\
\hline$F$-stat & $2.25^{\mathrm{b}}$ & $4.65 * *(++)$ & $2.67^{\mathrm{C}}$ & $3.28 * \mathrm{~d}$ \\
\hline
\end{tabular}

Notes: Same as for Table 2, except as follows.

${ }^{a}$ Rejects the null of no level relationship at 5\% (at 1\% in eq. 3) only under the condition that all variables are integrated of order zero.

${ }^{\mathrm{b}}$ Rejects the null of no level relationship, at $10 \%$ with the asymptotical critical values from Pesaran et al., only under the condition that all variables are integrated of order zero, and cannot reject the null of no relationship, at any significance level, with the small-sample critical values from Narayan.

${ }^{c}$ Rejects the null of no level relationship, at 5\% with the asymptotical critical values from Pesaran et al. and at $10 \%$ with the small-sample critical values from Narayan, only under the condition that all variables are integrated of order zero.

${ }^{\mathrm{d}}$ Rejects the null of no level relationship, at $5 \%$ with the small-sample critical values from Narayan, only under the condition that all variables are integrated of order zero. 


\section{Table 4}

Estimated demand functions for imports of intermediate goods including maquiladoras (dependent variable: IMPIM; sample period: 1960-2006, 47 annual observations).

\begin{tabular}{|c|c|c|c|c|}
\hline & $(1)^{\mathrm{a}}$ & (2) & (3) & (4) \\
\hline \multicolumn{5}{|l|}{ Long-run coefficients: } \\
\hline Speed of adjustment, $\sigma$ & -0.100 & -0.269 & -0.250 & -0.289 \\
\hline Gross domestic product, GDP & $2.57(0.04)$ & $0.53(0.03)$ & $0.29(0.34)$ & $0.42(0.14)$ \\
\hline Real exchange rate, BRER & $-0.19(0.90)$ & $-0.53(0.17)$ & $-0.27(0.56)$ & $-0.46(0.22)$ \\
\hline Manufactured exports incl. maquiladoras, EXPMM & & $0.71(0.00)$ & $0.86(0.00)$ & $0.80(0.00)$ \\
\hline GDP×DU87 & & & $-0.25(0.09)$ & \\
\hline BRER×DU87 & & & $0.72(0.12)$ & \\
\hline EXPMM×DU87 & & & & $-0.03(0.03)$ \\
\hline \multicolumn{5}{|l|}{ Diagnostics: } \\
\hline Adjusted $R^{2}$ & 0.604 & 0.761 & 0.834 & 0.791 \\
\hline Jarque-Bera & $4.17(0.12)$ & $0.44(0.80)$ & $0.02(0.99)$ & $0.16(0.93)$ \\
\hline Breusch-Godfrey & $1.25(0.27)$ & $1.20(0.28)$ & $0.71(0.40)$ & $0.70(0.41)$ \\
\hline ARCH & $0.96(0.33)$ & $0.46(0.50)$ & $0.27(0.61)$ & $0.15(0.70)$ \\
\hline RESET & $1.45(0.16)$ & $0.75(0.39)$ & $0.34(0.57)$ & $0.70(0.41)$ \\
\hline \multicolumn{5}{|l|}{ Bounds testing: } \\
\hline$t$-stat & $-2.17^{\mathrm{b}}$ & $-3.41 * *$ & $-3.32^{c}$ & $-3.16^{\mathrm{C}}$ \\
\hline F-stat & $1.72^{\mathrm{b}}$ & $4.05 * *(++)$ & $2.97 * \mathrm{~d}$ & $2.99^{\mathrm{e}}$ \\
\hline
\end{tabular}

Notes: Same as for Table 2, except as follows:

${ }^{a}$ Includes an intercept. The lag structure was not simplified, as that caused problems with the diagnostic tests.

${ }^{\mathrm{b}}$ Fails to reject the null of no level relationship, at any level of significance and order of integration of the variables.

${ }^{\mathrm{c}}$ Rejects the null of no level relationship at 5\% (at 1\% in eq. 3) only under the condition that all variables are integrated of order zero.

${ }^{\mathrm{d}}$ Rejects the null of no level relationship at $5 \%$ with the critical values from Narayan only under the condition that all variables are integrated of order zero.

${ }^{\mathrm{e}}$ Rejects the null of no level relationship, at $5 \%$ with the critical values from both Pesaran et al. and Narayan, only under the condition that all variables are integrated of order zero. 
Table 5

Actual GDP growth compared with BP-equilibrium growth and its determinants (averages for periods shown).

\begin{tabular}{|c|c|c|c|c|c|}
\hline \multirow[t]{2}{*}{ Period } & \multirow{2}{*}{$\begin{array}{c}\text { Whole sample } \\
\text { 1960-2006 }\end{array}$} & \multirow{2}{*}{$\begin{array}{c}\text { Pre-liberalization } \\
\text { 1960-1986 }\end{array}$} & \multirow{2}{*}{$\begin{array}{c}\text { Post-liberalization } \\
\text { 1987-2006 }\end{array}$} & \multicolumn{2}{|c|}{ Excluding oil boom and debt crisis } \\
\hline & & & & 1960-1977 & 1989-2006 \\
\hline Actual GDP growth rate (y) & 4.28 & 5.24 & 2.98 & 6.02 & 3.15 \\
\hline \multicolumn{6}{|l|}{ BP-equilibrium growth rate $\left(y_{B}\right):^{\text {a }}$} \\
\hline Excluding maquiladoras & 4.01 & 4.16 & 4.65 & 4.10 & 4.60 \\
\hline Including maquiladoras & 4.36 & 4.33 & 5.50 & 4.43 & 5.33 \\
\hline \multicolumn{6}{|l|}{ Average annual growth rates: ${ }^{\mathrm{b}}$} \\
\hline \multicolumn{6}{|l|}{ Manufactured exports $\left(x_{n}\right)$} \\
\hline Excluding maquiladoras & 11.24 & 11.82 & 10.45 & 12.90 & 9.29 \\
\hline Including maquiladoras & 12.94 & 13.95 & 11.58 & 15.54 & 10.23 \\
\hline Non-manufactured exports $\left(p^{*}{ }_{o}+x_{o}-p^{*}\right)$ & 5.81 & 5.57 & 6.13 & 4.52 & 6.98 \\
\hline \multicolumn{6}{|l|}{ Shares } \\
\hline \multicolumn{6}{|l|}{ Share of manufactures in total exports $(\mu)$} \\
\hline Excluding maquiladoras & $45.0 \%$ & $28.5 \%$ & $67.3 \%$ & $30.1 \%$ & $69.1 \%$ \\
\hline Including maquiladoras & $55.4 \%$ & $36.9 \%$ & $80.4 \%$ & $36.4 \%$ & $82.0 \%$ \\
\hline \multicolumn{6}{|l|}{ Share of intermediate goods in total imports $(\theta)$} \\
\hline Excluding maquiladoras & $55.6 \%$ & $49.1 \%$ & $64.5 \%$ & $40.7 \%$ & $63.6 \%$ \\
\hline Including maquiladoras & $62.2 \%$ & $52.3 \%$ & $75.5 \%$ & $43.0 \%$ & $74.9 \%$ \\
\hline \multicolumn{6}{|l|}{ Elasticities $^{c}$} \\
\hline GDP-elasticity of final goods imports $\left(\eta_{c}\right)$ & 1.58 & 1.10 & 1.56 & 1.10 & 1.56 \\
\hline \multicolumn{6}{|l|}{ GDP-elasticity of intermediate imports $\left(\eta_{i}\right)$} \\
\hline Excluding maquiladoras & 1.01 & 1.01 & 1.01 & 1.01 & 1.01 \\
\hline Including maquiladoras & 0.53 & 0.53 & 0.53 & 0.53 & 0.53 \\
\hline \multicolumn{6}{|c|}{ Manufactured-export elasticity of intermediate imports $(\alpha)$} \\
\hline Excluding maquiladoras & 0.51 & 0.51 & 0.51 & 0.51 & 0.51 \\
\hline Including maquiladoras & 0.71 & 0.71 & 0.71 & 0.71 & 0.71 \\
\hline
\end{tabular}

Sources: Authors' calculations; see appendix for underlying data sources.

${ }^{a}$ Calculated using equation (10).

${ }^{\mathrm{b}}$ All growth rates are measures as log differences in real series, where the nominal values were deflated using the US PPI for finished goods.

${ }^{\text {c }}$ Elasticities were taken from Tables $2-4$. See text for details. 


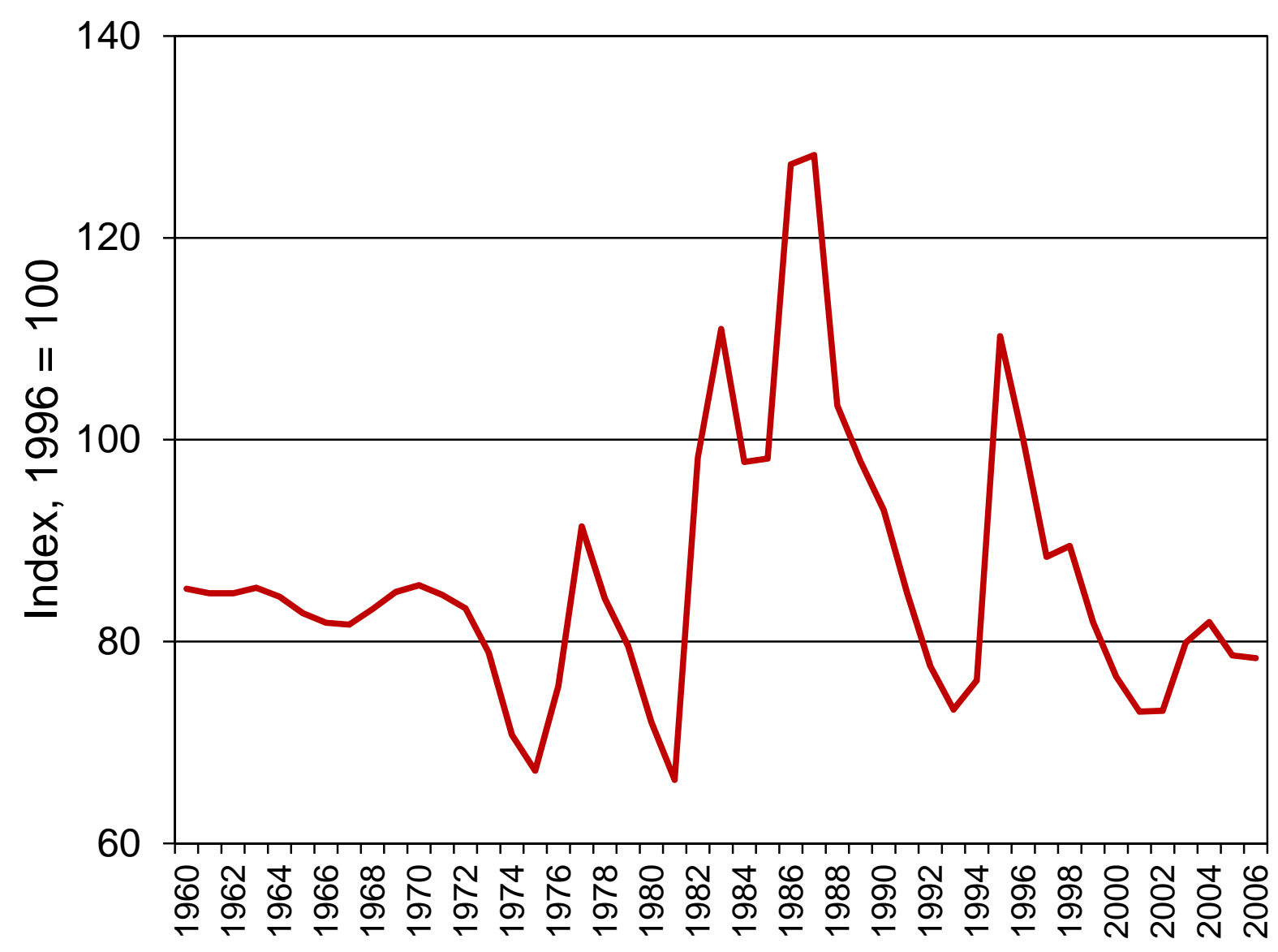

Note: The nominal exchange rate in pesos per dollar was multiplied by the ratio of the US CPI to the Mexican CPI. This index measures the relative price of foreign (US) goods, so a higher number indicates a real depreciation of the peso.

Fig. 1. Bilateral Mexican-US real exchange rate index (BRER), 1960-2006. 